\title{
MARKET VOLATILITY AND ITS IMPACT ON INVESTORS SENTIMENT
}

\begin{tabular}{|c|c|}
\hline KanteshaSanningammanavara & Dr. A Satya Nandini \\
Asst. Professor, Dept. of Management Studies and & Prof. and Head, Dept. of Management Studies and \\
Research Centre, Vidyavardhaka College of & Research Centre, BMS College of Engineering, \\
Engineering, Mysore - 570002 Mob: 9880423035 & Bangalore - 560019 Mob: 9844071921 \\
Email: kanteshvs@ gmail.com & Email: satyanandini@ @otmail.com \\
\end{tabular}

\begin{abstract}
The Volatility is such a worrisome that makes investment fraternity go back and think wisely before making any investment decisions. In that aspect this descriptive study analyses the market volatility in Indian Capital Market from last 24 years daily data set and model the same using advanced econometrics. The researchers have used the BSE Sensex as the benchmark to study volatility and applied GARCH(1) and ARCH(1) model where GARCH(1) studies about market volatility and ARCH(1) studies market return where we have used both model where we get GARCH(1,1) model. We have also tested which model will be suited to check stock market volatility and we checked with the three models they are Normal Gaussian Distribution, Student Fixed Distribution, Generalized Error Distribution and we came to conclusion that we can use any of the three models because it satisfies the entire hypothesis which we had. The researchers constructed investor's sentiment index to know till what level the investors' sentiment has its effect on the stock market volatility and we have understood by our study Market Volatility Causes the Investors Sentiment to the extent of 39.68\%. The researchers have used 3 Proxies like Current Day's Trade Volume, Previous Day's Trade Volume and, Previous Day's Closing Price to construct a sentiment indexand the study concludes that there is impact of market volatility on the investor sentiments.
\end{abstract}

Key Words - Market Volatility, Investor Sentiments, ARCH, GARACH, Granger Causality

JEL Code - G10, G11, G14, G17

\section{INTRODUCTION}

Market Volatility is one of the major issues faced by every investor. It is the major task of every finance manager to know where to invest in the market, and this will tell us that how investors will be facing the problem and how the market volatility is causing a problem to the economics of the country. Volatility in market in our country has been one of the major problems in our country Indian market is completely inefficient with so many and volatility of the market is also one of the main reasons for it.

There is always a great dramatic moment in capital market, stock prices appearing volatile by changes of fundamentals. Volatility is a great phenomenon as it's also a concept which remains one big concept for modern financial or capital market and for research in academic. Relationship between risk and volatility been to an extent is elusive; stock market volatility is certainly 
not a bad thing. Fundamentally volatility forms the basis efficient discovery of price. This context depends on volatility that it implies predictability by traders and it's also welcomed by medium- term investors. Volatility importance is spread wide in the financial economics.

Assets pricing models obtained equilibrium prices affected by volatility changes, management of investment depends upon the mean-variance theory, the valuation of derivatives reliable upon hinges volatility forecasts.

\section{LITERATURE REVIEW}

Bandivadekar and Ghosh (2003) studied the impact of introduction of index futures on spot market volatility on both S\&P CNX Nifty and BSE Sensex using ARCH/GARCH techniques. The researchers found that after the introduction of index futures there is steep decline in the volatility in the spot market that caused by news events and effect of uncertainty.

Hussain and Bashir (2013) investigated the dynamic linkages between exchange rate volatility and stock returns volatility of Pakistan, India and China for the period of five years from 2007 to 2012 by using daily data. GARCH model was applied to extract the volatility. The Johansen Co-integration test and Granger causality approach was used to test the relationship between exchange rate and stock returns volatility. The results shown that there is no causal relationship between exchange rate and stock returns volatility in India and China however for Pakistan it has been proved Fama (1981) attempted to explain the relationship between stock returns and inflation. The results shown that there is negative relation between stock returns and inflation and proxying for positive relations between stock returns and real variables that are fundamental determinants of equity value and author also evidenced that the negative stock return-inflation returns are induced negative relations between inflation and real variables.

\section{OBJECTIVES OF THE STUDY}

The Following are the Objectives of the Study

1. To Determine The Level of Market Volatility in the Indian Capital Market.

2. To Construct the Investors Sentiment Index using various selected proxies

3. To Analyze the Effect of Market Volatility on the Investors Sentiments.

\section{SCOPE OF THE STUDY}


This study will be able to give us a good idea about the Indian market volatility and the background of that volatility.

RESEARCH METHODOLOGY

Type of Research - Descriptive

Sampling Technique - Non Probability

Sampling

Type of Sample -Judgmental Sampling

Sample Size - 24 Years

Data Used - Secondary Data

Statistical Tests -ARCH, GARCH,

Causality Tests

Statistical Tools - Eviews, Stata

RESULTS AND DISCUSSION

Objective 1 - To Determine the Level of Market Volatility in the Indian Capital

\section{Market}

In this objective the researcher is modeling the Indian Stock Market Volatility using the time period of 24 years data starting from 1990 to 2014 . The Researcher used the daily lag returns of BSE Sensex data for understanding the volatility in the market and to model the same using $\operatorname{GARCH}(1,1)$ model. In the data set we have 5952 observations. The descriptive statistics of the data set show as below

\section{Table No 1 Showing the Unit Root Test}

\section{Hypothesis}

H0 - Sensex Lag Returns has a unit root (Data is not Stationary)
H1 - Sensex Lag Returns has no unit root (Data is stationary)

\begin{tabular}{|l|l|l|}
\hline Test type & t- & \\
\hline Augmented Dickey-Fuller & - & 0.000 \\
\hline From the above table the researcher
\end{tabular}
conclude that the lag returns of BSE Sensex are Stationarity at level (0).

\section{Development of ARCH and GARCH}

We are using GARCH $(1,1)$ Model to study the Sensex returns over 24 years. This means that in the model we use $1 \mathrm{ARCH}$ term and 1 GARCH term, so that we call it as $\operatorname{GARCH}(1,1)$

Let is discuss both the model in detail with Sensex return data

\section{Part 1 - Mean Equation}

$$
S R=C 1+e \ldots . .(1.1)
$$

Where,

$\mathrm{SR}=$ Daily Sensex returns, $\mathrm{C}=$ Constant, e $=$ Residual

We plot the residual desired from equation (1.1) as below Residual of BSE Sensex Returns for 5952 days

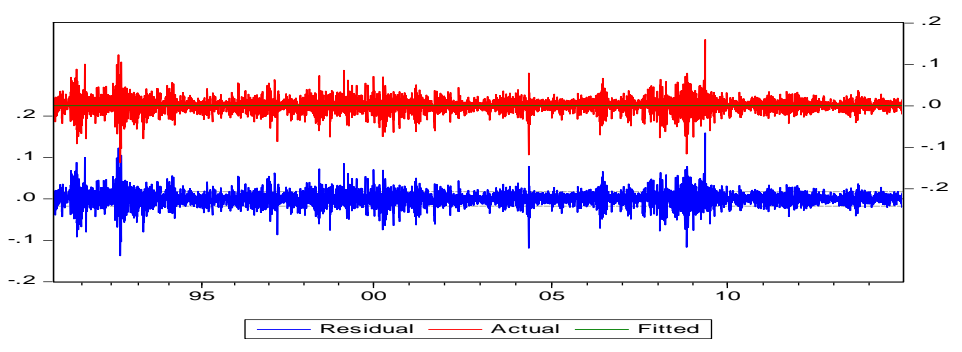

The above graph shows that when periods of high volatility are followed by period of 
high volatility and periods of low volatility tend to be followed by periods of low volatility. This suggests that (Behavior) residual or error term is conditionally heteroscedastic and it can be represented by ARCH and GARCH model (error)

So that the Mean Equation looks as below

$\mathrm{SR}=0.000598+\mathrm{e} \ldots \ldots(1.1)$

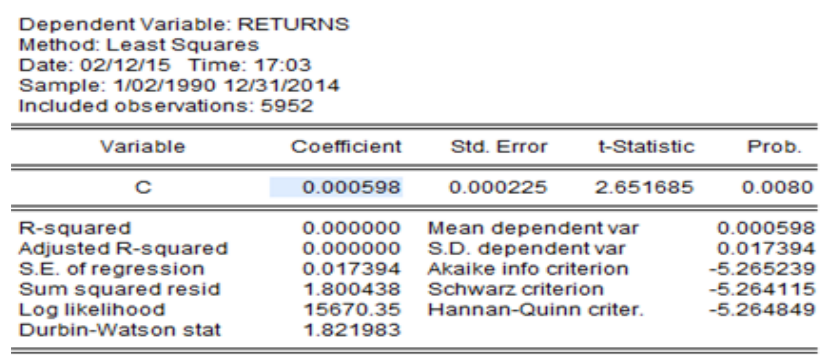

\section{Part 2 - Variance Equation (GARCH}

\section{(1.1)}

Residuals desired from mean equation (1.1) is used in making variance equation (1.2)

$\mathbf{H}_{\mathbf{t}}=\mathrm{C} 2+\mathrm{C} 3 \mathrm{H}_{\mathrm{t}^{-} 1}+\mathrm{C} \mathrm{e}^{2}{ }_{\mathrm{t}}$

$\mathbf{H}_{\mathbf{t}}=$ Variance of the residual derived from equation (1.1). It is also known as current days or variance or volatility of Sensex returns

$\mathrm{C} 3=$ Constant, $\mathrm{H}_{\mathrm{t}-1}=$ Previous days residual variance or Volatility of Sensex return's. It is also known as GARCH term, $\mathrm{e}_{\mathrm{t}-1}^{2}=$ Previous periods squared residual derived from equation (1.1). It is also known as previous day's bond returns information adequate volatility .It is ARCH term High order GARCH $(2,3)$ can be appointed also but many researchers prefer to use
GARCH (1.1) for modeling the volatility of bond return (better results). We shall estimate mean eq (1.1) and variance equation (1.2) simultaneous

\section{Our GARCH (1.1) model}

There, we have chosen daily data for estimating GARCH (1.1) model

\section{Results Discussion of GARCH (1.1) model}

Variance equation can be using three

Distribution and they are as below

1. Normal Gaussian distribution.

2. Student fixed distribution.

3. Generalized error Distribution Assumption.

\section{Normal Gaussian distribution}

- Under this ARCH should be significant. It means that previous days SENSEX information $(\mathrm{ARCH})$ can influence todays SENSEX volatility (That is $\mathrm{H}_{\mathrm{t}}$ in equation 1.2)

- GARCH should also be significant under NGD. It means that the previous days SENSEX volatility $\left(\mathrm{H}_{-1}\right.$ in equation 1.2 also known as GARCH) can inflow toady's SENSEX volatility.

- It means that SENSEX volatility is influenced by its own ARCH \& GARCH factors or own stocks

\section{$\underline{\text { Results of NGD }}$}


ELK

Asia Pacific Journals

\begin{tabular}{|c|c|c|c|c|}
\hline Variable & Coemcient & Std. Error & z-Statistic & Prob. \\
\hline c & 0.000916 & 0.000160 & 5.737843 & 0.0000 \\
\hline \multicolumn{5}{|c|}{ Variance Equation } \\
\hline $\begin{array}{l}C \\
\text { RESID }(-1)^{2} \\
\text { GARCH(-1) }\end{array}$ & $\begin{array}{l}3.57 E-06 \\
0.101624 \\
0.890091\end{array}$ & $\begin{array}{l}4.41 E-07 \\
0.005270 \\
0.004982\end{array}$ & $\begin{array}{l}8.091194 \\
19.28498 \\
178.6457\end{array}$ & $\begin{array}{l}\text { \%.0000 } \\
\text { \%.0ooo } \\
\text { 0.0000 }\end{array}$ \\
\hline $\begin{array}{l}\text { R-squared } \\
\text { Adjusted R-squared } \\
\text { S.E. of regression } \\
\text { sum squared resid } \\
\text { Log likelihood } \\
\text { Durbin-Watson stat }\end{array}$ & $\begin{array}{l}-0.000335 \\
-0.000335 \\
0.017397 \\
1.801041 \\
16604.22 \\
1.821374\end{array}$ & \multicolumn{2}{|c|}{$\begin{array}{l}\text { Mean dependent var } \\
\text { S.D. dependent var } \\
\text { Akaike info criterion } \\
\text { Schwarz criterion } \\
\text { Hannan-Quinn criter. }\end{array}$} & $\begin{array}{l}0.000598 \\
0.017394 \\
-5.578032 \\
-5.573535 \\
-5.576469\end{array}$ \\
\hline
\end{tabular}

\section{Students with fixed distribution}

Under this distribution all the below should

be significant

- $\mathrm{ARCH}$

- GARCH

\section{Results of SFD}

Dependent Variable: RETURNS

Method: ML - ARCH (Marquardt) - Student's t distribution

Date: 02/12/15 Time: $17: 36$

Sample: 1/02/1990 12/31/2014

Included observations: 5952

Convergence achieved after 8 iterations

Presample variance: backcast (parameter $=0.7$ )

t-distribution degree of freedom parameter fixed at 10

$\mathrm{GARCH}=\mathrm{C}(2)+\mathrm{C}(3)^{\star} \mathrm{RESID}(-1)^{\wedge} 2+\mathrm{C}(4)^{*} \mathrm{GARCH}(-1$

\begin{tabular}{crllr}
\hline \hline Variable & Coefficient & Std. Error & z-Statistic & Prob. \\
\hline \hline C & 0.000927 & 0.000163 & 5.702984 & 0.0000 \\
\hline \hline \multicolumn{5}{c}{ Variance } \\
\hline \hline Cquation \\
RESID $(-1)^{n} 2$ & $3.93 E-06$ & $6.92 E-07$ & 5.676861 & 0.0000 \\
GARCH(-1) & 0.103915 & 0.008411 & 12.35521 & 0.0000 \\
\hline \hline R-squared & 0.883283 & 0.008635 & 102.2968 & 0.0000 \\
Adjusted R-squared & -0.000358 & Mean dependent var & 0.000598 \\
S.E. of regression & -0.000358 & S.D. dependent var & 0.017394 \\
Sum squared resid & 0.017397 & Akaike info criterion & -5.615837 \\
Log likelihood & 1.801082 & Schwarz criterion & -5.611340 \\
Durbin-Watson stat & 16716.73 & Hannan-Quinn criter. & -5.614275 \\
\hline \hline
\end{tabular}

\section{GED with fixed Parameters}

Under this distribution all the below should

be significant

- $\mathrm{ARCH}$

- GARCH

Results of GED
ELK Asia Pacific Journals - Special Issue

ISBN: 978-81-930411-5-4

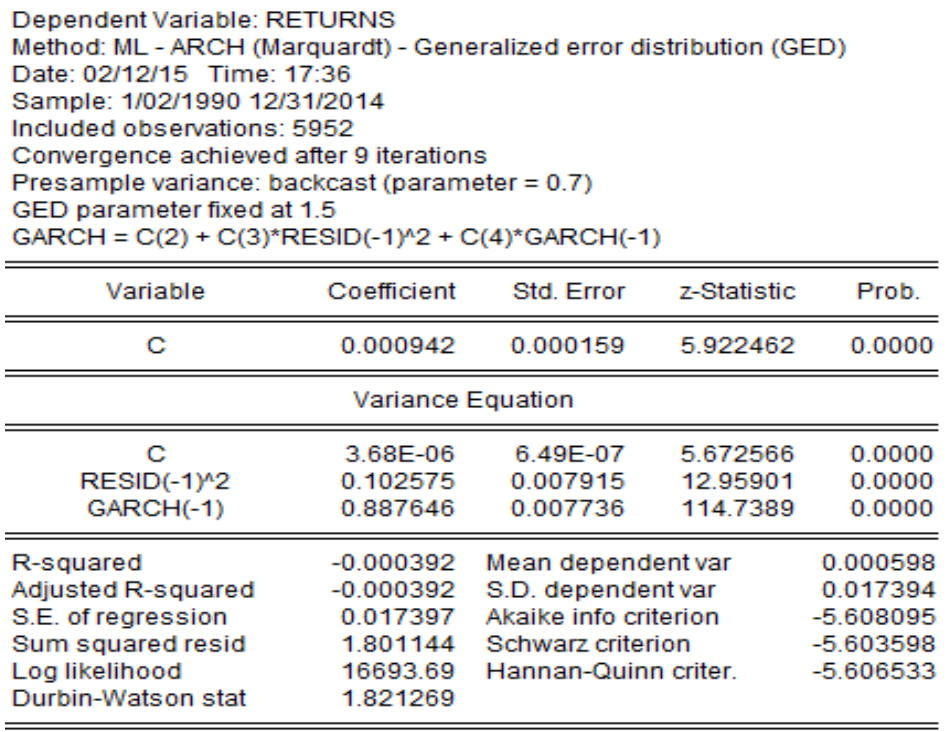

\section{Decision of the Model}

So we can conclude that volatility in SENSEX is largely dependent on its own stock such as ARCH and GARCH as they are significant under all the three distribution

\section{Model Selection\&Evaluation of Models under 3 Distribution}

Normal Gaussian distribution

Condition 1 - There is no Serial

\section{Correlation}

This has been tested using Correlogram square residual and $\mathrm{P}$-value for all the 36 lags are insignificant and the same has been shown below

\section{Condition 2 - There is no ARCH Effect}

This has been tested using Arch effect test 
Asia Pacific Journals

\begin{tabular}{|c|c|c|c|c|}
\hline $\begin{array}{l}\text { F-statistic } \\
\text { Obs*R-squared }\end{array}$ & $\begin{array}{l}1.121596 \\
1.121762\end{array}$ & \multicolumn{2}{|c|}{$\begin{array}{l}\text { Prob. F(1,5949) } \\
\text { Prob. Chi-Square(1) }\end{array}$} & $\begin{array}{l}0.2896 \\
0.2895\end{array}$ \\
\hline \multicolumn{5}{|c|}{$\begin{array}{l}\text { Test Equation: } \\
\text { Dependent Variable: WGT_RESIDn2 } \\
\text { Method: Least Squares } \\
\text { Date: O2/12/15 Time: } 17: 47 \\
\text { Sample (adjusted): } 1 / 03 / 199012 / 31 / 2014 \\
\text { Included observations: } 5951 \text { arter adjustments }\end{array}$} \\
\hline Variable & Coefficient & Std. Error & t-Statistic & Prob. \\
\hline WVT_RESID'2(-1) & $\begin{array}{l}0.986691 \\
0.013730\end{array}$ & $\begin{array}{l}0.028890 \\
0.012964\end{array}$ & $\begin{array}{l}34.15291 \\
1.059054\end{array}$ & $\begin{array}{l}0.0000 \\
0.2896\end{array}$ \\
\hline $\begin{array}{l}\text { R-squared } \\
\text { Adjusted R-squared } \\
\text { S.E, of regression } \\
\text { Sum squared resid } \\
\text { Log likelihood } \\
\text { F-statistic } \\
\text { Prob(F-statistic) }\end{array}$ & $\begin{array}{r}0.000188 \\
0.000020 \\
1.991479 \\
23593.67 \\
-12542.61 \\
1.121596 \\
0.289618\end{array}$ & \multicolumn{2}{|c|}{$\begin{array}{l}\text { Mean dependent var } \\
\text { S.D. dependent var } \\
\text { Akaike info criterion } \\
\text { Schwarz criterion } \\
\text { Hannan-Quinn criter. } \\
\text { Durbin-Watson stat }\end{array}$} & $\begin{array}{l}1.000427 \\
1.991500 \\
4.215969 \\
4.218217 \\
4.216750 \\
1.999408\end{array}$ \\
\hline
\end{tabular}

This has been tested using Jarque-Bera

\section{Condition 3 - The Residuals are normally}

statistics

\section{distributed}
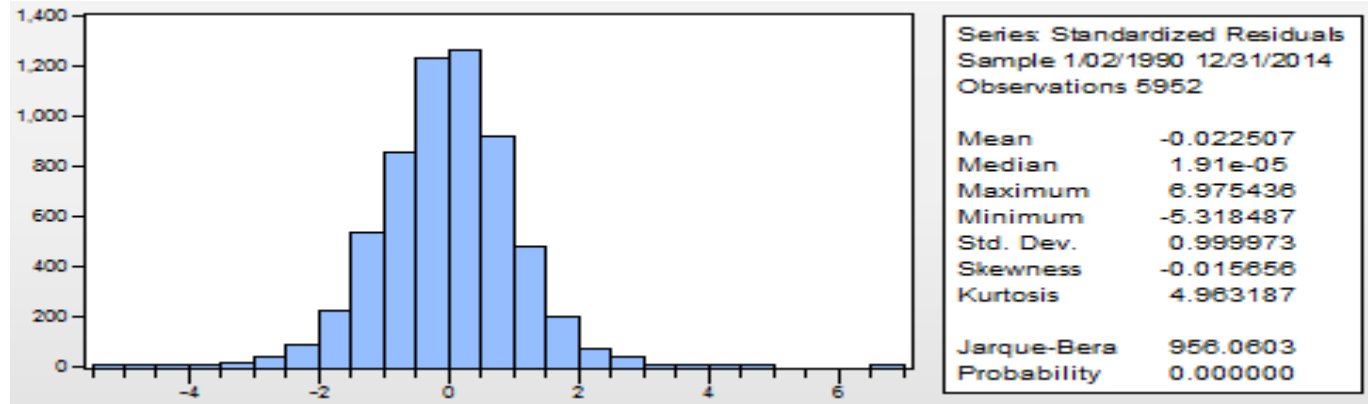

lags are insignificant and the same has been

STUDENT FIXED DISTRIBUTION.

Condition 1 - There is no Serial

\section{Correlation}

This has been tested using Correlogram

square residual and P-value for all the 36

\begin{tabular}{|c|c|c|c|c|}
\hline $\begin{array}{l}\text { F-statistic } \\
\text { Obs"R-squared }\end{array}$ & $\begin{array}{l}0.648044 \\
0.648192\end{array}$ & \multicolumn{2}{|c|}{$\begin{array}{l}\text { Prob. } F(1.5949) \\
\text { Prob. Chi-Square (1) }\end{array}$} & \multirow[t]{2}{*}{$\begin{array}{l}0.4208 \\
0.4208\end{array}$} \\
\hline \multicolumn{4}{|c|}{$\begin{array}{l}\text { Test Equation: } \\
\text { Dependent Variable: WGT_RESID^2 } \\
\text { Method: Least Squares } \\
\text { Date: O2/12/15 Time: } 20: 29 \\
\text { Sample (adjusted): } 1 / 03 / 199012 / 31 / 2014 \\
\text { Included observations: } 5951 \text { after adjustments }\end{array}$} & \\
\hline Variable & Coefficient & Std. Error & t-Statistic & Prob. \\
\hline$\underset{\text { WGT_RESID } 2(-1)}{C}$ & $\begin{array}{l}1.018786 \\
0.010437\end{array}$ & $\begin{array}{l}0.029811 \\
0.012965 \\
\end{array}$ & $\begin{array}{l}34.17532 \\
0.805012\end{array}$ & $\begin{array}{l}0.0000 \\
0.4208\end{array}$ \\
\hline $\begin{array}{l}\text { R-squared } \\
\text { Adjusted R-squared } \\
\text { S.E. of regression } \\
\text { Sum squared resid } \\
\text { Log likelihood } \\
\text { F-statistic } \\
\text { Prob(F-statistic) }\end{array}$ & $\begin{array}{r}0.000109 \\
-0.000059 \\
2.056273 \\
25153.91 \\
-12733.15 \\
0.648044 \\
0.420845\end{array}$ & $\begin{array}{l}\text { Mean depen } \\
\text { S.D. depend } \\
\text { Akaike info C } \\
\text { Schwarz crite } \\
\text { Hannan-Quir } \\
\text { Durbin-Wats }\end{array}$ & $\begin{array}{l}\text { int var } \\
\text { it var } \\
\text { erion } \\
\text { on } \\
\text { criter. } \\
\text { istat }\end{array}$ & $\begin{array}{l}1.029531 \\
2.056212 \\
4.280003 \\
4.282252 \\
4.280784 \\
1.999426\end{array}$ \\
\hline
\end{tabular}

shown below

\section{Condition 2 - There is no ARCH Effect}

This has been tested using Arch effect test 
Condition 3 - The Residuals are normally distributed
This has been tested using Jarque-Bera statistics

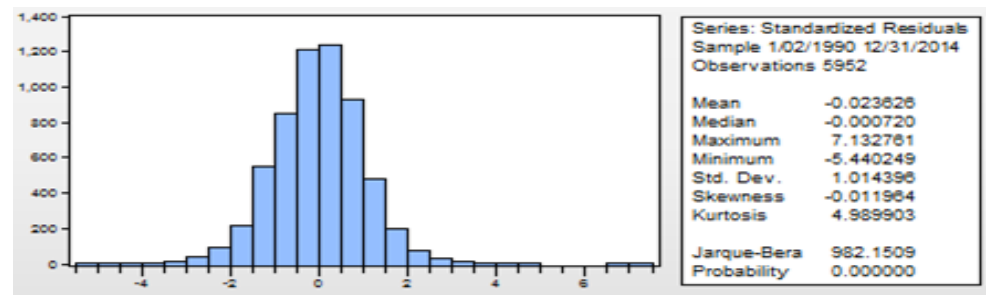

\section{GENERALIZED \\ ERROR}

\section{DISTRIBUTION ASSUMPTION}

Condition 1 - There is no Serial

\section{Correlation}

This has been tested using Correlogram square residual and P-value for all the 36 lags are insignificant and the same has been shown below

\section{Condition 2 - There is no ARCH Effect}

This has been tested using Arch effect test
Heteroskedasticity Test: ARCH

\begin{tabular}{|c|c|c|c|c|}
\hline $\begin{array}{l}\text { F-statistic } \\
\text { Obs*R-squared }\end{array}$ & $\begin{array}{l}0.919983 \\
0.920150\end{array}$ & \multicolumn{2}{|c|}{$\begin{array}{l}\text { Prob. } F(1,5949) \\
\text { Prob. Chi-Square(1) }\end{array}$} & $\begin{array}{l}0.3375 \\
0.3374\end{array}$ \\
\hline \multicolumn{5}{|c|}{$\begin{array}{l}\text { Test Equation: } \\
\text { Dependent Variable: WGT_RESID^2 } \\
\text { Method: Least Squares } \\
\text { Date: O2/12/15 Time: } 20: 32 \\
\text { Sample (adjusted): } 1 / 03 / 199012 / 31 / 2014 \\
\text { Included observations: } 5951 \text { after adjustments }\end{array}$} \\
\hline Variable & Coefficient & Std. Error & t-Statistic & Prob. \\
\hline $\begin{array}{c}\text { C } \\
\text { WGT_RESID^2(-1) }\end{array}$ & $\begin{array}{l}0.998294 \\
0.012435\end{array}$ & $\begin{array}{l}0.029217 \\
0.012964\end{array}$ & $\begin{array}{l}34.16807 \\
0.959157\end{array}$ & $\begin{array}{l}0.0000 \\
0.3375\end{array}$ \\
\hline $\begin{array}{l}\text { R-squared } \\
\text { Adjusted R-squared } \\
\text { S.E. of regression } \\
\text { Sum squared resid } \\
\text { Log likelihood } \\
\text { F-statistic } \\
\text { Prob(F-statistic) }\end{array}$ & $\begin{array}{r}0.000155 \\
-0.000013 \\
2.014435 \\
24140.73 \\
-12610.82 \\
0.919983 \\
0.337518\end{array}$ & \multicolumn{2}{|c|}{$\begin{array}{l}\text { Mean dependent var } \\
\text { S.D. dependent var } \\
\text { Akaike info criterion } \\
\text { Schwarz criterion } \\
\text { Hannan-Quinn criter. } \\
\text { Durbin-Watson stat }\end{array}$} & $\begin{array}{l}1.010864 \\
2.014421 \\
4.238890 \\
4.241139 \\
4.239672 \\
1.999413\end{array}$ \\
\hline
\end{tabular}

\section{Condition 3 - The Residuals are normally}

\section{distributed}

This has been tested using Jarque-Bera statistics

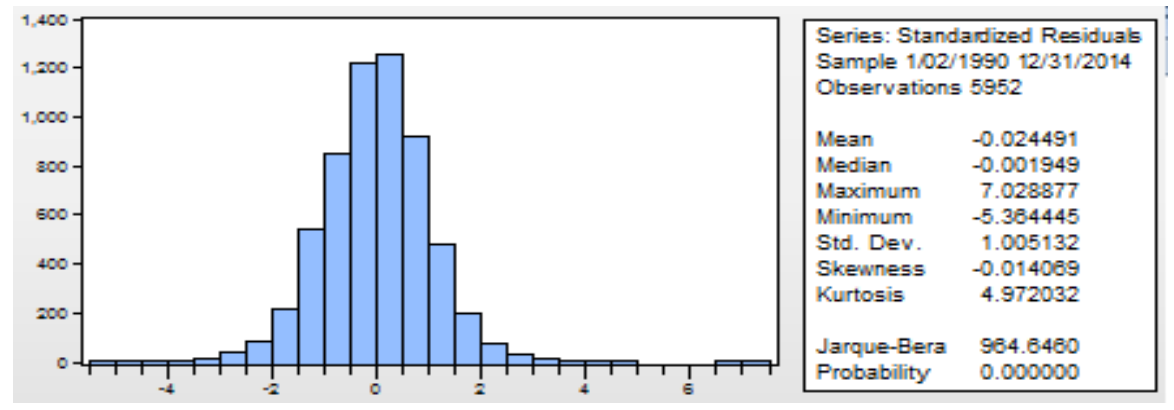

The weakness of these three distributions is non-normality of residuals but many suggests that non-normality in the residual may not be that serious problem as estimators are still consistent.

\section{Conclusion}

- We can take either of 3 models as best models.

- We can also use the best model for forecasting of SENSEX.

Objective 3 - To construct the Investors sentiment Index 
To construct Investors Sentiment Index, we used the Current Day's Trade Volume, Previous Day's Trade Volume andPrevious Day's Closing Price

To construct the Sentiment Index, the researcher used 24 years daily data. In the data set there are 5951 observations

Table No 6 Showing the Descriptive of the same is shown below

\begin{tabular}{|l|l|r|r|r|r|l|}
\hline & Mean & Median & Maximum & Minimum & Std. Dev. & Obs \\
\hline SENSEX & 8682.545 & 4625.4 & 28693.99 & 659.3 & 7025.907 & 5959 \\
\hline SENTIMENT INDEX & 27364.25 & 4731.12 & 385386.9 & 659.3 & 29360.38 & 5959 \\
\hline
\end{tabular}

Objective 4 - To analyze the effect of market volatility on the Investors Sentiment Index

For this we run regression analysis

Dependent Variable - Investors Sentiment

Independent Variable - BSE Sensex

Table Showing Results of Regression

\begin{tabular}{|c|c|c|c|c|}
\hline Variable & Coefficient & Std. Error & $\mathrm{t}$-Statistic & Prob. \\
\hline$\stackrel{C}{\mathrm{C}}$ & $\begin{array}{l}4500.366 \\
2633917\end{array}$ & 469.7606 & $\begin{array}{l}9.580128 \\
62.59583\end{array}$ & $\begin{array}{l}0.0000 \\
0.0000\end{array}$ \\
\hline $\begin{array}{l}\text { R-squared } \\
\text { Adjusted R-squared } \\
\text { S.E. of regression } \\
\text { Sum squared resid } \\
\text { Log likelihood } \\
\text { F-statistic } \\
\text { Prob(F-statistic) }\end{array}$ & $\begin{array}{r}0.396814 \\
0.396713 \\
22805.80 \\
3.10 \mathrm{E}+12 \\
-68240.20 \\
3918.238 \\
0.000000\end{array}$ & \multicolumn{2}{|c|}{$\begin{array}{l}\text { Mean dependent var } \\
\text { S.D. dependent var } \\
\text { Akaike info criterion } \\
\text { Schwarz criterion } \\
\text { Hannan-Quinn criter. } \\
\text { Durbin-Watson stat }\end{array}$} & $\begin{array}{l}27361.1: \\
29361.8 \\
22.9077^{!} \\
22.9100 \text { i } \\
22.9085: \\
0.12267:\end{array}$ \\
\hline
\end{tabular}

\section{Model}

ISI $=\alpha+\beta$ Sensex $+\varepsilon$

Sensex Variable in the above analysis is Significant and will be part of the Model ISI $=4500.366+2.63$ Sensex $+\varepsilon$

The R-Squared is 0.3968 . This means the Market Volatility Causes the Investors Sentiment to the extent of $39.68 \%$

\section{CONCLUSION}

Concluding this we can say there are several factors which are having its effect on the stock market and there are several reasons for its volatility there is no one reason for it.Where in our research we were only able to come out with only $59.8 \%$ factors of the stock market volatility and there are several other factors than what we have gone through. The researchers have constructed our own sentiment index by using different proxies like Current Day's Trade Volume, Previous Day's Trade Volume and, Previous Day's Closing Price by that we have come calculated the level till what level the investor's sentiments are affected by the stock market volatility. Investor's sentiment is affected up to $39.8 \%$ by the stock market volatility in Indian, by sentiment index we are able to understand that we can know that the knowledge level of the investors in the stock market. 
Asia Pacific Journals

There are models like ARCH and GARCH

model where ARCH model studies about the return of the market and the GARCH model studies about the Stock market volatility of India, we have used GARCH $(1,1)$ model which will tell us about the stock market volatility, we can also say that out of NGD, GED, SED anyone model can be used to check the stock market volatility in India.There several model in GARCH but GARCH $(1,1)$ is considered has the best model to check the stock market volatility. By this study as a student I am able to understand and come to know about the stock market volatility and the several factors of it and I have come to know about the models like GARCH and ARCH model to know about the stock market volatility in the India and we have identified several macro and micro factors for the volatility and there effects and its impact on the stock market volatility.

\section{REFERENCES}

[1] Agarawal, G., \& Srivastava, A. (2011). Stock Market Retuns and Exchange Rates Volatility: A GARCH Application. Research Jounals of International Studies, 20, 12-23.

[2] Aggarwal, R. (1981). Exhange Rates and Stock Prices: A Study of the U S
Capital Markets under floating exchange rates. Journal of Financial Research, 19, 193-207.

[3] Bandivadekar, S., \& Ghosh, S. (Winter 2003). Derivatives and Volatility on Indian Stock Markets. Reserve Bank of India Occasional Papers, 24(3), 187-201.

[4] Fama, E. F. (Sept 1981). Stock Returns, Real Activity, Inflation, and Money. The American Economic Review, 71(4), 545-565.

[5] Gabaix, X., Plerou, P. G., \& Stanley, H. E. (2005). Institutional Investors and Stock Market Volatility. NBER Working Paper No 11722, 1-50.

[6] Grouard, M. H., Levy, S., \&Lubochinsky, C. (2003). Stock market Volatility: From Empirical Data to their Interpretation. Banque De France, FSR, 57-74.

[7] Hassan, A. M. (2003). Financial Integration of Stock Markets in the Gulf: A Multivariate Cointegration Analysis. International Journal of Business, 8(3), 335-346.

[8] Hussain, M., \& Bashir, U. (2013). Dynamic Linkages of Exchange Rate and Stock Returns Volatility Evidence from Pakistan, India and China(PIC). International Review of 
Asia Pacific Journals

Management and Business Research, 2(2), 345-354.

[9] Ibrahim, M. H. (1999). Economic Variables and Stock Prices in Malaysia: An Empirical Analysis. Asian Economic Journal, 13(2), 219231.

[10] Islam, M. M. (2003). The Kuala Lumpur Stock Market and Economic Factors: A General-tospecific error correction modeling test. Journal of Academy of Business and Economics, 1(1), 1-20. 